\title{
Building Bridges and Growing Wings through Doctoral Education: A Literary Meta-Analysis
}

\author{
Ryan Rominger ${ }^{1}$, Ph.D., LCPC-PIT \\ 1 Associate University Research Chair, Center for Leadership Studies and Educational Research, School of \\ Advanced Studies, University of Phoenix, USA \& Adjunct Research Faculty, Sofia University, California Institute of \\ Integral Studies, USA \\ Correspondence: Ryan Rominger, Ph.D., LCPC-PIT, 440 Rominger Lane, Floweree, MT 59440, USA
}

Received: April 3, 2018

Accepted: June 4, 2018

Online Published: June 12, 2018

doi:10.5430/ijhe.v7n3p171

URL: https://doi.org/10.5430/ijhe.v7n3p171

Disclosure: This study was unfunded, and no conflict of interest exists between the author and study constituents or components.

\section{Acknowledgements}

I would like to acknowledge the support and encouragement of Dr. Mark McCaslin, Dean, mentor, colleague, and friend. Your guidance and encouragement were instrumental for completion of the study.

\begin{abstract}
Doctoral education evolves amidst changing international social and educational pressures. New programs emerge, while current programs re-evaluate educational processes. This literary meta-analysis reviewed national and international literature in order to understand what issues are currently debated within higher education. Results indicate three main categories: "Connection with Non-Doctoral Education Groups;" "Re-visioning the Doctoral Education Process;" and "Aligning Dissertation/Capstone Projects with Type of Doctoral Program." Within the categories, eleven themes also emerged. Implications of the study include expanded understanding for new and revised doctoral programs to remain aware of the increasing influence of industry upon education, with industry remaining the main employment location for most doctoral graduates.
\end{abstract}

Keywords: doctoral education, meta-analysis, industry, capstone projects

\section{Introduction}

\subsection{Introducing the Problem}

Structures and andragogy of higher education continue to develop amidst national and international pressures, ranging from increasing student debt and questions regarding financial aid to movements attempting to increase civic, community, and business engagement with doctoral degree output (New England Resource Center for Higher Education, 2016; The Woodrow Wilson National Fellowship Foundation, 2005). As structure and pedagogy come under scrutiny, questions arise regarding sustainability and applicability. How will doctoral education meet the educational needs of the next generation of scholars? What changes are discussed most frequently within the education literature, and what innovations are most prominent on the educational landscape? More importantly, which changes enhance doctoral education, and which changes might provide a doctoral program an advantage over competitors?

Educational leaders ask these questions, and many more, when considering programmatic revisions, introducing a new program, or investigate solutions for problems which have emerged within a doctoral program (Lee \& Danby, 2012). Often educational leaders must cull through copious amounts of texts including books, conference proceedings, articles, and non-profit or government reports in order gain a better understanding of recent discussions in the field. However, few articles provide an overview of the many discussions which occur within the broader higher education literature. The current study attempted to fill this gap through completion of a literary meta-analysis of current doctoral program and higher education literature.

\subsection{Literature Review}

Doctoral education has progressed through numerous changes since its development in medieval Europe in the 1200 's, when it was primarily focused on law, medicine, and theology (Nerad, 2014). During the reformation, 
doctoral education was used to advance priests and church administrators using theology and law, and during the enlightenment doctoral education shifted to philosophy, humanities, and the natural sciences in an effort to create new knowledge (Nerad, 2014). According to Nerad (2014) the modern era of doctoral education and the research university emerged, with a goal of fostering research and research-based training. However, the modern era has had its own developmental phases.

Walker et al. (2008) have identified five stages within modern American doctoral education. The first stage occurred from the late 1880s through the 1930s, and was exemplified by scholars traveling to Germany, returning, and bringing the German Humboldtian educational traditions back to American when founding American doctoral programs (Kehm \& Teichler, 2016; Osakwe et al., 2015; Walker et al., 2008). The Humboldtian tradition included two specific components: research and teaching, with the new American model of doctoral education attempting to unify the two. Stage two occurred post World War II, from 1940 to 1960s and has been referred to as the Golden Age of higher education (Walker et al., 2008). During this time, graduate education expanded, new doctoral schools opened at the rate of one per week, and the number of doctoral students exploded. This growth was largely funded by expanded government programs supporting research within universities, and thus doctoral education. Unfortunately, the growth did not last, and the third stage was ushered in during the 1970s. During this third stage, federal financial support receded, student populations declined, and the doctoral programs were faced with a changing social milieu (Walker et al., 2008). The choice was to promote changes within higher education or become obsolete. Changes included expanding doctoral education to older students, lower income students, and many programs became more applied, focused on solving local and national problems.

Stage four occurred as another shift occurred within higher education: diversification of the student population starting in the 1980s and 1990s (Walker et al., 2008). This meant greater numbers of women and people from diverse backgrounds. Additionally, the numbers of degree programs once again started increasing. However, the presumed aging-out of older faculty failed to materialize, which meant that many doctorates had to find other avenues of employment. Rather than entering into academia, doctoral grads in increasing numbers entered into industry and the labor force (Gokhberg, Shmatko, \& Auriol, 2016; Walker et al., 2008).

According to Walker et al. (2008), the fifth stage of development within modern higher education started in the 1990 s and continued through the 2000s, with increasing global competition and national organizations such as the Council of Graduate Schools (CGS) engaged in studying the current changes and offering direction through policy statements for American higher education. Whether we remain in stage five is debatable, however there appears to be a clear shift toward increasing awareness of the globalization of higher education (Gokhberg, Shmatko, \& Auriol, 2016; Lee \& Danby, 2012; Nerad, 2014; Nerad \& Evans, 2014). As more doctorates enter into industry instead of academia, nation states recognize the impact of doctorates on Gross National Product and economic stability (Nerad \& Evans, 2014). Additionally, doctorates have become increasingly mobile, moving within countries and between countries, with more international policies (such as the European Bologna Process) impacting a global understanding of higher education (Kehm, 2010; Kehm, \& Teichler, 2016; Lee \& Danby, 2012; Nerad \& Evans, 2014). Finally, doctoral education has become increasingly tied to industry, especially considering most doctorates are how hired into industry instead of academia post-graduation (Gokhberg, Shmatko, \& Auriol, 2016).

One key example of a stage five (Walker et al., 2008) development in the United States includes The Woodrow Wilson National Fellowship Foundation's (2005) endeavor to study what the organization called The Responsive Ph.D. The foundation collaborated with 20 graduate schools, engaged in a review of recent literature on doctoral education, and discovered a set of four primary principles which undergird four primary themes. The first principle is that "the Ph.D. degree requires strong graduate schools and graduate deans with real budgets and real scope-a far stronger central administrative structure than typically exists at present" (p. 4). Thus, it would be imperative to strengthen the graduate school structure, placing it at the center of a research institution. The second principle is that "the doctorate...will benefit enormously by a continuing interchange with the worlds beyond academia. The doctorate needs to be opened to the world and to engage social challenges more generously" (p. 5). This interchange comes through dialogue and partnerships with government, businesses, cultural institutions, and non-profits. The third principle is that doctoral education must engage the "breadth of the populace" (p. 7). This principle emphasizes the need to engage people from all backgrounds and cultures, which may require supporting education (and encourage later pursuit of doctoral education) in non-traditional educational institutions (such as community colleges) and within culturally diverse populations. The fourth and final principle is that doctoral education must be assessed in a coherent way which attaches specific benefits, and consequences, to specific outcomes. Stronger assessment of outcomes will promote stronger academic excellence as seen through a larger social and community impact of doctoral education. 
These four principles stand behind four main themes generated by The Woodrow Wilson National Fellowship Foundation (2005). First, a Responsive Ph.D. engages new "partnerships with constituents both within and beyond the university" (p. 12). This effectively means doctoral programs collaborating with all levels of education starting with K-12, as well as leaders in government, business, and cultural institutions. Second, a Responsive Ph.D. engages new paradigms of doctoral education, engaging innovation and opening traditionally closed structures. "In doctoral education, a person on fire with an interest gets the go-ahead to take that interest to its limit, to engage with mastery and seek to make our world more habitable and rich" (p. 15). This exploration may include transdisciplinary work, in addition to collaboration with institutions beyond the academic setting. Third, a Responsive Ph.D. engages new practices and, specifically, teaching and service, "which really mean the application of expertise in the broader society" (p. 17). The application may come in the form of practical application of knowledge, but it also comes in the form of structures in the doctoral program which promote learning the art of teaching. Fourth, a Responsive Ph.D. engages new people. Traditionally, individuals of color, disability, or lower socioeconomic standing have not been encouraged, en mass, to attend graduate school nor provided the resources to succeed. The Responsive Ph.D. encourages the democratization of doctoral education.

For example, service learning is a "pedagogical technique combining academic learning with community service" (Martin, 2015). In a service learning model, students engage community groups and businesses outside of the school in order to further the educational process. Service learning may also benefit the business or organization through the innovative ideas and youthful energy brought by the students. This approach also connects school, community, business, and organization constituents, introduces students to diverse populations, and encourages practical application of course room learning all while building student skills. Service learning continues to expand in the educational domain and is used especially within business and marketing disciplines (Martin, 2015). For business and marketing programs in particular, service learning is viewed as an antidote to current problems within the fields by providing "reality, reflection, reciprocity, and responsibility" (p. 111). Service learning also helps fill community needs by placing masters and doctoral students within community organizations, which may be particularly helpful within non-profit organizations which may have few resources to hire specialists within the business and marketing domains. Martin (2015) indicates it is clear that service learning is growing in popularity within academia; however, the value may yet be underappreciated. It is also unknown how service learning has been applied specifically within doctoral programs. Finally, it is important to note that service learning, while not unique to doctoral education, is clearly related to The Responsive PhD's first theme, that of engaging constituents outside of doctoral education.

\subsection{Problem Statement, Significance, and Research Question}

Clearly the field has continued to develop since the 2005 publication of The Responsive Ph.D. It remains unclear, however, what the different influential factors may be, nationally and internationally, or what the current literary discussion landscape looks like, with regard to higher education. For those in leadership positions, administering doctoral education, planning revisions to current programs, or creating new programs proceeding without awareness of current trends could be detrimental, if not fatal, to the programs especially in an era of increasing portability and international program enrollment. This literary analysis, targeting published literature focused on higher education (Ph.D., Ed.D., DBA, DNP, etc.), provides an overview of that landscape and thus provides a better understanding of some of the key topics under discussion within higher education.

\section{Method}

This meta-analytic study investigated current trends in doctoral education. The purpose was to expand awareness of current discussions at the national and international levels in higher education, establish a set of themes present in current doctoral education literature, and report on these current trends. Knowing the current trends in doctoral education literature allows further flexible, innovative development of doctoral education which (a) meets the high standards expounded in The Responsive Ph.D. and Martin's (2015) Service Learning, while also (b) meeting the unique needs of a diverse set of students, including those who are already working in the marketplace. The results will be directly applicable to current or new doctoral programs which wish to remain on the forefront of educational pedagogy.

This study utilized a literature review meta-analysis. The literature review included literature written in the past 10 years (with a few exceptions where literature led to topical discussions dating back 15 years, which this author felt compelled to include for a better understanding of the full discussion), with selection criteria focused on: (a) doctoral education pedagogy; (b) doctoral education options regarding capstone or dissertation project structures; (c) innovations in community-business-doctoral education relationship development; (d) education structures focused on the working professional; (e) accrediting agency standards for doctoral education; (f) accreditation agency 
conference presentations and publications regarding doctoral education; and (g) accreditation agency conference presentations and publications on meeting unique needs of the working professional.

To establish a list of resources, a 'seed' metaphor was used. In this case, the seed metaphor is similar to snowball sampling used in human subjects research, where one participant refers two others, and those two refer two more, growing into a larger participant population. Several key texts were collected, and from these initial 'seeds' a fuller literature base was grown. Those sources which emerged from the initial 'seeds' included literature from organizations discussed within the texts, references used within the texts, and library database searches based on text discussions. The initial 'seed' literature included three books and 10 articles (Appendix A). This 'seed' developed into seven main books and over 50 articles, conference proceedings, national and international organization reports, and accreditation websites (Appendix B).

Literature was reviewed for prominent themes using structural, in vivo, and evaluation coding (Saldaña, 2009). Established themes were further refined through successive, iterative coding. 34 codes were then mapped using an online mind-mapping program, allowing for development of major categories and exploration of relationships between categories and specific themes. The mind-map, key categories, and themes were further refined into three main categories with 11 main themes.

\section{Results}

Three main categories and 11 primary themes emerged from the literary meta-analysis. The three main categories were: "Connection with Non-Doctoral Education Groups;" "Re-visioning the Doctoral Education Process;" and "Aligning Dissertation/Capstone Projects with Type of Doctoral Program." Within each category, a number of themes demonstrated the topics found within current literature and ongoing discussions regarding doctoral education. Finally, a bi-directional reciprocal impact was noticed between each category, with each category demonstrating influence upon each other category. Visually this may be depicted as a triangle, with a category at each apex, and bi-directional arrows between each apex (Figure 1).

\section{Connection with}

Non-Ed Groups
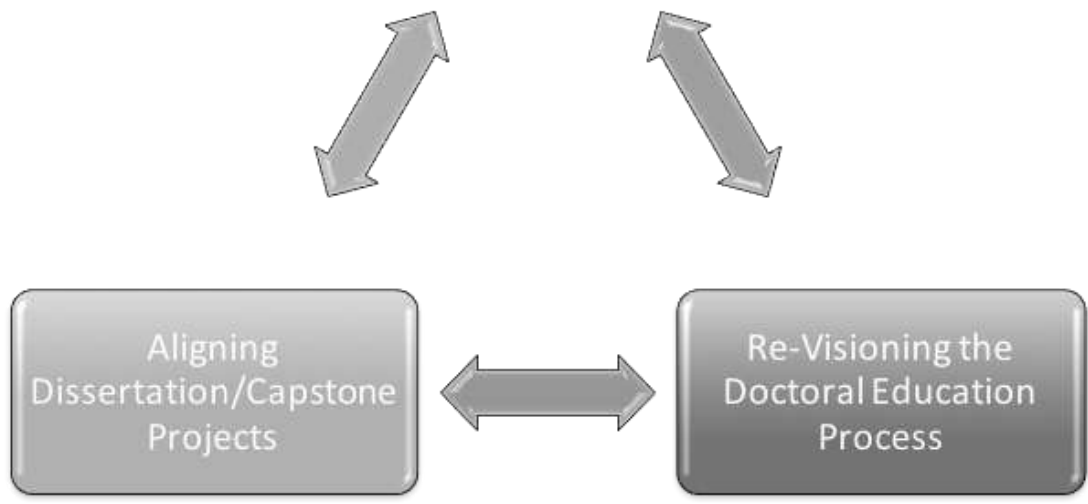

Figure 1. Main Emergent Categories of Literary Meta-analysis

\subsection{Emphasis on Connections Outside the Graduate Program}

As noted in the introduction to this paper, even within The Responsive Ph.D. there was a recognition of the need to enhance connections beyond the graduate program. The call for increased connections continues. The first category in the present study's findings, Connection with Non-Doctoral Education Groups, demonstrates continued discussion of how to achieve the best possible interactions between doctoral programs and other constituents. Graduate programs are encouraged to reach out to local, state, national, and international organizations including community, non-profit, business, and government organizations. These relationships may be more or less formal, may offer potential placement opportunities for graduates, could increase dialogue around graduate readiness for professional 
placement (thus influencing graduate program and curriculum), and may even provide funding opportunities. In Australia Cooperative Research Centres [sic], organizations created to connect university, industry, and the government, have existed for decades and offered doctoral students government funding, a liminal space to transact university and business relationships, space for integration of multiple domains of knowledge, and opportunities for practical professional application of knowledge in the world (Adkins, Summerville, Danby, \& Matthews, 2012). Connections may also include other graduate programs, particularly when cross-disciplinary or multi-mentoring situations arise (Walker, Golde, Jones, Conklin Bueschel, \& Hutchings, 2008).

The four main themes, representative of discussions within extant literature, which emerged within this category pertain to the types of organizations with which doctoral programs might connect. They are connections with (a) government organizations, (b) non-profit organizations, (c) business and industry, and (d) community organizations. The connections between doctoral programs and these external groups are acknowledged as potential career pathways for graduates (Gokhberg, Shmatko, \& Auriol, 2016). In some cases, doctoral graduates are already embedded within an industry, and seeking a doctorate to advance knowledge, skills, and job placement. In other cases, graduate students may enter the named industry either to complete a doctoral capstone project or enter upon graduation, if not before, as an employee. Alternatively, doctoral grads may work in one domain, such as education, and later move domains by entering the business or government sectors (Gokhberg, Shmatko, \& Auriol, 2016). Additionally, another major topic of conversation within the literature was that generating relationships with organizations in turn influenced the doctoral programs by providing necessary input regarding the needs of the industry, current research needs, current industry-specific skills required upon graduation, and information on the application of academic theory and models.

\subsection{Re-visioning the Doctoral Educational Process}

A number of themes arose within the broader category of Re-visioning the Doctoral Educational Process. Those themes included: (a) teaching teaching, (b) collaborative learning, (c) creating an intellectual community, (d) pedagogy of research, (e) multi-mentoring relationship/team supervision, and (f) disciplinarity versus interdisciplinarity. It is widely recognized that doctoral education is shifting, particularly as governments, accreditation agencies, and research organizations deepen their assessment of the effectiveness of doctoral education. For example, the Council of Graduate Schools continues to release studies of different aspects of graduate education, including the shifting patterns of doctoral education. In their December 7-9, 2016 conference, topics included the future of the dissertation, the role of mentoring in graduate education, lessons from business-school partnerships, and creating solid online graduate programs.

Regarding the first theme, teaching teaching, the Carnegie Foundation study on graduate education uncovered a clear support for efforts toward shifting doctoral education so that it enhances the teaching of the teaching process itself (Walker, Golde, Jones, Bueschel, \& Hutchings, 2008). These efforts arose out of growing awareness that doctoral graduates were not obtaining the teaching skills required in today's market. The teaching of teaching (skills) may include courses on pedagogy as well as increased opportunities for graduate students to engage in the teaching process (such as teaching undergraduate courses) while receiving feedback on syllabi, course interactions, and teaching technologies (Walker, Golde, Jones, Conklin Bueschel, \& Hutchings, 2008).

Regarding the remaining themes, a number of sources supported collaborative learning, wherein students engaged in the larger learning community. Engagement with peers, faculty, and other department members was reported to deepen and enhance knowledge of the discipline and engage cross-discipline dialogue. Similarly, multi-mentor relationship or team supervision of doctoral students (and their research) was felt to enhance graduate student experiences, providing more consistent support for students, possibly decrease time to completion, and engage the student in cross-discipline discussion and application. However, there were still concerns that multiple mentors could lead to communication problems (cross-talk, pitting faculty against each other, overburdening the student and faculty, mixed messages regarding content and methods, etcetera) and may be viewed by more traditional faculty as usurping of their role as mentor to an apprentice. However, together multi-mentoring relationships and collaborative learning were thought to help establish another important aspect of emerging doctoral paradigms: the intellectual community.

Two final themes in this domain were encouraging a pedagogy of research and disciplinarity versus interdisciplinarity. A pedagogy of research (Walker, Golde, Jones, Conklin Bueschel, \& Hutchings, 2008) is an approach wherein the research endeavor is taught at all levels of graduate education, and not simply within research courses. For example, the research process may be broadly defined as finding a gap in understanding or defining a research problem, establishing a research question, determining a method of answering the question, collecting data or information, and coming to a conclusion about the question under investigation. This process could be replicated 
at a singular class level by starting a class (or even one particular day's topic) with definition of a gap in student understanding, reiteration of what the students need to know to fill that gap, covering the content, and discussion of the content (data) which answers the main question at hand. Similarly, an entire course could be construed in the same way, with the definition of a larger question (the topic for the course), review of what the students will need to know (what data they need to collect) to answer that question (which is ultimately the weekly class content), and then a summary at the end of the course to integrate the 'data' into a coherent explanation of the initial question. When used overtly, students see how the research process can be applied to many settings, and nurtures students to conceptualize problem formation and solution within a research process paradigm.

The final theme of disciplinarity versus interdisciplinarity is one which arose often, and with much debate. Some graduate faculty support creating a solid foundation within a single discipline, which can then be used widely to engage other settings or disciplines. However, increasingly literature is discussing the inherent interdisciplinarity when graduate students engage real-world problems. Sugimoto (Council of Graduate Schools, 2016) reports that graduate students are increasingly engaging scientific endeavors in heterogeneous settings outside of academia, leading to growing interdisciplinarity. She supported the position that dissertations (or capstone projects) should prepare students for interdisciplinarity, rather than impose strict adherence to academia-focused disciplinary structures. Similarly, the Carnegie Institute reported that integrative learning helps graduate researchers "make connections across settings and over time-from one course to another, from one discipline to another, between the classroom and community settings, and among the domains of teaching, research, and academic service" (Huber \& Hutchings, 2004; as cited in Walker, Golde, Jones, Conklin Bueschel, \& Hutchings, 2008, p. 76).

\subsection{Aligning Dissertations and Capstones with Type of Doctoral Program}

The themes within this domain, Aligning Dissertations and Capstones with Type of Doctoral Program, largely relate to the overarching expansion of doctoral education to increasingly and overtly include a Boyer domain of Discovery plus Application (Boyer, 1996; Osakwe, Keavey, Uzoka, Fedoruk, \& Osuji, 2015). Traditional dissertations within the sciences have focused on the Boyer domain of Discovery, which involves the search for new knowledge and sharing that knowledge through traditional publication and presentation routes. Current literature, however, challenges the sole focus of research on discovery and appears to encourage recognition of research Application as well (as is found in practitioner-oriented doctoral degrees). In Boyer's model, Application refers to discovering ways that new knowledge can be put to work in the world, solving real world problems.

Related to a revisioning of doctoral education across the Boyer domains, there is also increasing recognition of the many types of doctoral programs. Often a 'doctoral' program is equated with obtaining a Doctor of Philosophy, or $\mathrm{Ph} . \mathrm{D}$. However, there is a long history of other doctoral degrees such as the M.D., J.D., and Ed.D. Higher education has continued to develop doctoral degrees, with more recent additions of doctorates in nursing and business, for example. Kehm and Teichler (2016), when reviewing doctoral programs around the globe, noted nine general categories of doctorates: the research doctorate, the taught doctorate, Ph.D. by published work, the professional doctorate, the practice-based doctorate, the 'new' doctorate, two models of joint doctorate, the cooperative doctorate, and the industrial doctorate (see pp. 16-23). A problem arises, though, when the doctorates are held in the same research-focus as the Ph.D., which uniquely emphasizes research and research methodology. This creates a conflict, as the non-research-Ph.D. doctorates are most often practitioner or profession focused, with the goal of building experts who can practice within a specific industry. Therefore, discussion continues regard the alignment between the doctoral capstone project, most often a dissertation, and the expected program outcomes within the practitioner doctoral programs. Thus, a main category within discussing dissertations and capstones is the alignment between capstone or dissertation projects and the doctoral program. The themes in this category are: practice-based output; alternative models for dissertations and capstone projects; and engagement in the world.

Practice-based output includes dissertation and capstone projects which go beyond traditional research housed primarily within an educational institution. These projects may include action research projects within organizations aimed at helping facilitate organization change, creation and execution of business plans or project management plans, or professional practice projects focused on efficacy studies in nursing, therapy, or other helping professions. While traditional research has its value, with increasing collaboration between graduate schools and community organizations, businesses, non-profits, and government organizations, questions arise as to how the dissertation project might better adjust to these emerging relationships and position the graduate for engagement in the professional world. Practice-based output appears to be one answer to the question.

A second answer is found within the second, related, sub-theme of alternative models of dissertation and capstone projects. Rather than creating a singular, book-length written document, students might be encouraged to create more 
profession-appropriate output. Sugimoto's (CGS, 2016) call to action can again be heard here: Ph.D. graduates are increasingly asked to publish in collaborative, peer-reviewed articles or to create industry-specific content. The book-length dissertation is increasingly misaligned with teaching graduates for this future work, and thus use of the dissertation as a demonstration of professional output is increasingly outdated. Alternative models may include publication of multiple peer-reviewed articles, engagement in collaborative research outputs, creation of pertinent business documents (organizational analysis, business plans, etc.), or creation of innovative programs to help individuals and communities solve todays problems, to name a few. The point is to break the mold of the traditional dissertation and open up options for alignment of graduate school output with real-world problems and real-world solutions which have practical application.

The third theme follows suit: engagement with the world. This theme is related to application of knowledge in the world. For over a century and a half American graduate education in architecture has struggled with the issue of knowledge about architecture or knowledge of (or within) architecture (Rice \& Matthews, 2012). The essential argument is, does a graduate know, objectively, the theory of architecture, or can the graduate actually engage in the practice of architecture. Professional doctoral programs invariably struggle with a similar dilemma: knowledge about, or knowledge in. Capstone projects must demonstrate the ability to practice within a professional domain, and thus need to be aligned for that assessment process. Engagement with the world also encompasses translational skills. Graduate students must be able to communicate professionally with both the academy and the professional domain (nursing, counseling, education, business administration). Thus, it is important to create a capstone project which further develops and displays (for assessment) these translational skills.

Another aspect of this theme is that of enacted knowledge. Just as translational skills are necessary, professional or industry skills are often required. For those remaining in academic settings, industry skills relate to typical research skills of literature review, writing of lengthy documents, analysis of data, and contextualizing data analysis within discipline-specific discussions. However, with doctorates increasingly employed outside of academic settings, professional or industry skills may transcend traditional skills to include managing research or working groups, managing budgets, communicating across numerous contexts including social media, working with increasingly diverse populations, and engaging both national and international organizations and peoples. Thus, non-traditional dissertations or capstone projects could be aligned to demonstrate these additional professional skills.

\section{Conclusion}

This meta-analysis, while completed at this point and time, is far from over, and the above categories and themes should be considered dynamic. They will undoubtedly shift as discussion of doctoral education, much like doctoral education itself, continues to evolve and develop. Overt discussions are now held regarding assessment of current doctoral educational practices, and how we might change both assessment and andragogical practices. In no instance have I discovered an author who proposed doctoral education should remain the same, with the same style of dissertation, same structure of apprenticeship, and same style of diffused leadership within doctoral programs. Clearly opportunities are arising for further defining doctoral education, including doctoral education for the professional doctorate.

\subsection{Limitations}

As with all research, the present study was hampered by several limitations. First, this study was restricted by budget and time. With funding, more researchers, or more time many more resources could have been reviewed providing an even clearer picture of the ongoing dialogue occurring within higher education. Even so, this research was able to reach a point of saturation, where new articles provided little new by way of categories of discussion, often fitting within the framework established by the current analysis. Second, collection of materials and analysis occurred between August 2016 and September of 2017. Materials may have been published during this time, or since, which could change the outcome of this meta-analysis. Third, the analysis could have been influenced by the researcher's own bias. I have worked within doctoral education for 20 years, have taught in doctoral programs for 11 years, and been an administrator in doctoral programs for a combined 4 years. I have worked in non-profit and for-profit education and am currently an administrator in a for-profit institution which is primarily practitioner-oriented. These personal experiences may have influenced the lenses utilized for data analysis. However, this potential bias also provides a unique insight into ongoing discussions within higher education (Moustakas, 1990).

\subsection{Future Research}

Because higher education continues to face a variety of challenges, from loss of federal student loan payback opportunities to increasing numbers of doctoral programs and increasing global mobility of student populations, the 
literature discussing doctoral education should be continually monitored. Future research may wish to identify specific discussions which are occurring within specific types of doctoral programs. For example, while this study included articles on all doctoral programs, the types of discussions occurring within business doctoral programs may be quite different from discussions occurring within physics programs. Similarly, discussions may be different between hard-science Ph.D. programs and the social science Ed.D. programs. Finally, future research may wish to devote additional resources to developing a catalog of type of material reviewed (organization reports, government reports, studies on capstone projects, books reporting non-profit initiatives, accreditation agency materials, etcetera), topics under discussion, conclusions from the material, and implications for doctoral education. Ideally, the research would include more funding and increased numbers of researchers working jointly in order to reduce potential bias and increase number of materials which may be reviewed (as occurred within The Responsive Ph.D. project within which this article started).

\section{Acknowledgements}

I would like to acknowledge the support and encouragement of Dr. Mark McCaslin, Dean, mentor, colleague, and friend. Your guidance and encouragement were instrumental for completion of the study.

\section{References}

Adkins, B., Summerville, J., Danby, S., \& Matthews, J. (2012). Pedagogies of industry partnership. In A. Lee \& S. Danby (Eds.), Reshaping doctoral education: International approaches and pedagogies (pp. 156-169). New York, NY: Routledge.

Boyer, E. L. (1996). From scholarship reconsidered to scholarship assessed. Quest, 48(2), 129-139. https://doi.org/10.1080/00336297.1996.10484184

Council of Graduate Schools. (2016). Dissertation forward: Rethinking the PhD Thesis. A workshop with Christopher Loss and Cassidy Sugimoto. Author. Retrieved at: https://www.youtube.com/watch?v=VElB_2kQqRc\&feature=youtu.be

Gokhberg, L., Shmatko, N., \& Auriol, L. (Eds.). (2016). The science and technology labor force: The value of doctorate holders and development of professional careers. Switzerland: Springer International. https://doi.org/10.1007/978-3-319-27210-8

Kehm, B.M. (2006). Doctoral education in Europe and North America: A comparative analysis. In U. Teichler (Ed.), The formative years of scholars, Vol. 83, (pp. 67-78). Wenner - Gren International Series. London: Portland Press.

Kehm, B. M. (2010). Quality in higher European education: The influence of the Bologna Process. Change, May/June, 40-46. https://doi.org/10.1080/00091381003704677

Kehm, B. M., \& Teichler, U. (2016). Doctoral education and labor market: Policy questions and data needs. In L. Gokhberg, N. Shmatko, \& K. Auriol (Eds.), The Science and Technology Labor Force (pp. 11-29). Switzerland: Springer International. https://doi.org/10.1007/978-3-319-27210-8_2

Lee, A., \& Danby, S. (Eds.) (2012). Reshaping doctoral education: International approaches and pedagogies. New York, NY: Routledge.

Martin, M. C. (2015). Service learning as marketing pedagogy: Practical, theoretical, and institutional perspectives. Academy of Educational Leadership Journal, 19(2), 109-127.

Moustakas, C. (1990). Heuristic research: Design, methodology, and applications. Newbury Park, CA: Sage. https://doi.org/10.4135/9781412995641

Nerad, M., \& Evans, B. (Eds.) (2014). Globalization and its impacts on the quality of PhD education: Forces and forms in doctoral education worldwide. Boston, MA: Sense Publishers/Center for Innovation and Research in Graduate Education. https://doi.org/10.1007/978-94-6209-569-4

Osakwe, C., Keavey, K., Uzoka, F. M., Fedoruk, A., \& Osuji, J. (2015). The relative importance of academic activities: Autonomous values from the Canadian professoriate. Canadian Journal of Higher Education, 45(2), $1-22$.

Rice, C., \& Matthews, L. (2012). Designing (in) the PhD in architecture. In A. Lee \& S. Danby (Eds.), Reshaping doctoral education: International approaches and pedagogies (pp. 99-112). New York, NY: Routledge.

Saldaña, J. (2009). The coding manual for qualitative researchers. Los Angeles, CA: Sage. 
The New England Resource Center for Higher Education. (2015). The Next Generation Engagement Project. Boston, MA: University of Massachusetts. atrieved http://www.nerche.org/index.php?option=com_content $\&$ view=article \&id=355\&Itemid=96

The Woodrow Wilson National Fellowship Foundation. (2005). The Responsive Ph.D.: Innovations in U.S. doctoral education. Princeton, NJ: Author.

Walker, G. E., Golde, C. M., Jones, L., Conklin Bueschel, A., \& Hutchings, P. (2008). The formation of scholars: Rethinking doctoral education for the twenty-first century. San Francisco, CA: The Carnegie Foundation for the Advancement of Teaching.

\section{Appendix A}

\section{Seed Resources Used to Start Meta-Analysis}

Alberti, V. (2015). The hard work of preserving the value of doctoral education. The case of the Ph.D. in Regional and Urban Planning at Sapienza, Rome. Italian Journal of Planning Practice, 5(1), 132-157. http://ijpp.uniroma1.it/index.php/it/article/view/56/44

Banerjee, S., \& Morley, C. (2013). Professional Doctorates in Management: Toward a Practice Based Approach to Doctoral Education. Academy of Management Learning \& Education, 12(2), 173-193. doi:10.5465/amle.2012.0159

Buss, R. R., Zambo, D., Painter, S. R., Moore, D. W. (2013). Examining Faculty Member Changes in an Innovative Educational Doctorate Program Innovative Higher Education, 38(1), 59-74. doi:10.1007/s10755-012-9222-3

Byrne, J., Jørgensen, T., \& Loukkola, T. (2013). Quality assurance in doctoral education: Results of the ARDE Project.

EUA

Publications. https://brjk.amu.edu.pl/_data/assets/pdf_file/0018/224262/EUA_ARDE_Publication.pdf

Gokhberg, L., Shmatko, N., \& Auriol, L. (Eds.). (2016). The science and technology labor force: The value of doctorate holders and development of professional careers. Switzerland: Springer International.

Michael, M. J., \& Clochesy, J. M. (2016). From scientific discovery to health outcomes: A Synergistic model of doctoral nursing education. Nurse Education Today, 40, 84-86. DOI: http://dx.doi.org/10.1016/j.nedt.2016.02.011

Nerad, M., \& Evans, B. (Eds.) (2014). Globalization and its impacts on the quality of PhD education: Forces and forms in doctoral education worldwide. Rotterdam, Netherlands: Sense Publishers (Center for Innovation and Research in Graduate Education).

Saunders, D. B., Kolek, E. A., Williams, E. A., \& Wells, R. S. (2016). Who is shaping the field? Doctoral education, knowledge creation and postsecondary education research in the United States. Higher Education Research \& Development. Published online Feb., 2016. Doi: 10.1080/07294360.2016.1139552

The Woodrow Wilson National Fellowship Foundation. (2005). The Responsive Ph.D.: Innovations in U.S. doctoral education. Princeton, NJ: Author.

Walker, G. E., Golde, C. M., Jones, L., Conklin Bueschel, A., \& Hutchings, P. (2008). The formation of scholars: Rethinking doctoral education for the twenty-first century. San Francisco, CA: The Carnegie Foundation for the Advancement of Teaching. 


\section{Appendix B}

\section{Complete List of Resources Reviewed for Meta-Analysis}

Alberti, V. (2015). The hard work of preserving the value of doctoral education. The case of the Ph.D. in Regional and Urban Planning at Sapienza, Rome. Italian Journal of Planning Practice, 5(1), 132-157. http://ijpp.uniroma1.it/index.php/it/article/view/56/44

Allum, J.R., Kent, J.D. and McCarthy, M.T. (2014). Understanding PhD Career Pathways for Program Improvement: A CGS Report. Washington, DC: Council of Graduate Schools.

Ampaw, F.D. \& Jaeger, A.J. (2012). Completing the three stages of doctoral education: An event History analysis. Research in Higher Education, (53), 640-660. doi:10.1007/s11162-0119250-3 http://link.springer.com/article/10.1007/s11162-011-9250-3\#/page-1

Anderson, N. C. (2013). Effective Doctoral Education: Interpreting Factors and Outcomes of Success through a New Framework, Autoethnography, and Quantitative Study of Passion. Doctoral Dissertation, North Dakota State University. Proquest/UMI: ISBN: 978-1-3035-6399-7 ERIC Number: ED563710

Auriol, L., Misu, T., Galindo-Rueda, F., \& Colecchia, A. (2013). Key findings of the OECD KNOWINNO Project on the careers of doctorate holders. Sponsored by EU's Seventh Framework Programme and NISTEP-Japan. Completed under the Programme of Work and Budget of the OECD's Committee on Science and Technology Indicators. Retrieved at: https://www.oecd.org/sti/inno/CDH\%20FINAL\%20REPORT-.pdf

Banerjee, S., \& Morley, C. (2013). Professional Doctorates in Management: Toward a Practice Based Approach to Doctoral Education. Academy of Management Learning \& Education, 12(2), 173-193. doi:10.5465/amle.2012.0159

Barden, M., Bendsoe, M., Bungartz, H., Canavero, F., Coninx, L, de Jong, E., . . \& Wedel, M. (2015). Innovative doctoral training at universities of science and technology: Discussion paper. A joint discussion paper between five European university associations-CEASAR, CLUSTER, EuroTech Universities Alliance, IDEA League, and Five Tech presented in Brussels, October 13, 2015. Retrieve at: http://www.cesaer.org/en/newsitems/news/innovative-doctoral-training-at-universities-of-science-and-technolog ydiscussion-paper-now-availabl/

Bartunek, J. M. (2014). Academic-practitioner relationships: What NTL started and what Management scholarship keeps developing. Journal of Applied Behavioral Sciences, 50(4), 401-422. doi: 10.1177/0021886314548671

Beetham, H. \& Sharp, R. (Eds.). (2013). Rethinking Pedagogy for a Digital Age: Designing for 21st Century Learning. New York, NY: Routledge. ISBN-13: 978-0415539975

Browne-Ferrigno, T., \& McEldowney Jensen, J. (2012). Preparing Ed.D. Students to Conduct Group Dissertations. Innovative Higher Education, 37(5), 407-421. doi:10.1007/s10755012-9212-5

Buss, R. R., Zambo, D., Painter, S. R., Moore, D. W. (2013). Examining Faculty Member Changes in an Innovative Educational Doctorate Program Innovative Higher Education, 38(1), 59-74. doi:10.1007/s10755-012-9222-3

Byrne, J., Jørgensen, T., \& Loukkola, T. (2013). Quality assurance in doctoral education: Results of the ARDE Project. $\quad$ EUA https://brjk.amu.edu.pl/_data/assets/pdf_file/0018/224262/EUA_ARDE_Publication.pdf

Publications.

Council of Graduate Schools. (2016). The future of the doctoral dissertation. Conference proceedings of 15 presentations. Retrieved at: http://cgsnet.org/future-doctoral-dissertation

Council of Graduate Schools. (2016). Dissertation forward: Rethinking the PhD Thesis. A workshop with Christopher Loss and Cassidy Sugimoto. Author. Retrieved at: https://www.youtube.com/watch?v=VElB_2kQqRc\&feature=youtu.be

Davis, G., \& Fiske, P. (1999). Results of the 1999 PhDs.org Graduate School Survey. $<$ http://www.phds.org/reading/NSBHandout.html>.

European Commission, European Research Area (ERA), Steering Group Human Resources and Mobility (ERA SGHRM). (2011). Using the Principles for Innovative Doctoral Training as a Tool for Guiding Reforms of Doctoral Education in Europe. Report. Retrieved https://euraxess.ec.europa.eu/belgium/jobs-funding/doctoral-training-principles

Fine Knowles, M., \& Harleston, B. (1997). Achieving diversity in the professoriate: Challenges and opportunities. 
Washington, D.C.: American Council on Education.

Golde, C.M. (2001). Findings of the survey of doctoral education and career preparation: A report to the Compact for Faculty Diversity. Unpublished manuscript, University of Wisconsin at Madison.

Golde, C.M., \& Dore, T.M. (2001). At cross purposes: What the experiences of doctoral students Reveal about doctoral education. Philadelphia, PA: A report prepared for The Pew Charitable Trusts <http://www.phd-survey.org>.

Green, P., \& Bowden, J. A. (2015) Moral compass framework: Individual and collective decision making in some complex doctoral education scenarios. International Journal for Researcher Development, 6(1), 9 - 23.

Grossman, S. C., Kazer, M. W., Wheeler, K., Conelilus, J., Shea, J., \& Moriber, N. (2013). Transforming Doctoral Education for Nurse Practitioners through The Clinical Portfolio. Presentation at $39^{\text {th }}$ Annual National Organization of Nurse Practitioner Faculties (NONPF), Washington, DC. https://nonpf.confex.com/nonpf/2013pa/webprogram/Paper6082.html

Hay, A. \& Samra-Fredricks, D. (2016). Desperately seeking fixedness: Practitioners' accounts of 'becoming doctoral researchers'. Management Learning, 47(4), 407-423. doi: 10.1177/1350507616641599

Holley, K. A. (2015). Doctoral education and the development of an interdisciplinary identity. Innovations in Education and Teaching International, 52(6), 642-652. http://dx.doi.org/10.1080/14703297.2013.847796

Gokhberg, L., Shmatko, N. \& Auriol, L. (Eds.) (2016). The Science and Technology Labor Force: The Value of Doctorate Holders and Development of Professional Careers. Switzerland: Springer International. ISBN 978-3-319-27208-5

Kehm, B. M. (2010). Quality in higher European education: The influence of the Bologna Process. Change, May/June, 40-46.

Kehm, B. M., \& Teichler, U. (2016). Doctoral education and labor market: Policy questions and data needs. In L. Gokhberg, N. Shmatko, \& K. Auriol (Eds.), The Science and Technology Labor Force (pp. 11-29). Switzerland: Springer International.

Lee, A., \& Danby, S. (Eds.) (2012). Reshaping doctoral education: International approaches And pedagogies. New York, NY: Routledge. ISBN-13: 978-0415618137

Lotz-Sisitka, H., Wals, A. E., Kronlid, D., McGarry, D. (2015). Transformative, transgressive Social learning: rethinking higher education pedagogy in times of systemic global dysfunction. Current Opinion in Environmental Sustainability, 16, 73-80. doi:10.1016/j.cosust.2015.07.018

Martin, M. C. (2015). Service learning as marketing pedagogy: Practical, theoretical, and institutional perspectives. Academy of Educational Leadership Journal, 19(2), 109-127.

Michael, M. J., \& Clochesy, J. M. (2016). From scientific discovery to health outcomes: A Synergistic model of doctoral nursing education. Nurse Education Today, 40, 84-86. DOI: http://dx.doi.org/10.1016/j.nedt.2016.02.011

Moriber, N. A., Wallace-Kazer, M., Shea, J., Grossman, S., Wheeler, K., \& Conelius, J. (2014). Transforming doctoral education through the clinical electronic portfolio. Nurse Educator, 39(5), 221-226. doi: 10.1097/NNE.0000000000000053

National Conference on Graduate Student Leadership Proceedings. (2003) St. Louis, MO: Washington University in St. Louis, Graduate School of Arts and Sciences. 〈http://www.artsci.wustl.edu/GSAS/ncgsl2003>.

Nerad, M. (2000). The Ph.D.-Ten Years Later. Presentation at the Re-envisioning the Ph.D. conference. <http://www.grad.washington.edu/envision/project_resources/2000_conf_pages/2000_panel_surveys.html>.

Nerad, M., \& Evans, B. (Eds.) (2014). Globalization and its impacts on the quality of PhD education: Forces and forms in doctoral education worldwide. Rotterdam, Netherlands:

Sense Publishers (Center for Innovation and Research in Graduate Education). ISBN 978-94-6209-569-4

Nyquist, J.D., \& Woodford, B.J. (2000). Re-envisioning the Ph.D.: What are our concerns? Seattle, WA: University of Washington, Center for Instructional Development and Research $<$ http://www.grad.washington.edu/envision/PDF/ConcernsBrief.pdf $>$.

Olson, K., \& Clark, C. M. (2009). A Signature Pedagogy in Doctoral Education: The Leader Scholar Community 
Educational Research, 38(3), 216-221. doi: 10.3102/0013189X09334207

Orr, M. T. (2015). Implications of the 2011 U.S. Survey of Doctoral Education in Leadership Preparation. International Journal of Educational Reform, 24(3), 309-315.

Osakwe, C., Keavey, K., Uzoka, F. M., Fedoruk, A., \& Osuji, J. (2015). The relative importance of academic activities: Autonomous values from the Canadian professoriate. Canadian Journal of Higher Education, 45(2), $1-22$.

Raelin, J. A., \& Coghlan, D. (2006). Developing managers as learners and researchers: Using Action learning and action research. Journal of Management Education, 30(5), 670-689. doi: 10.1177/1052562905285912

Sadlak, J. (Ed.). (2004). Doctoral Studies and Qualifications in Europe and the United States: Status and Prospects. UNESCO. Studies Higher an Retrieved http://unesdoc.unesco.org/images/0013/001364/136456e.pdf

Saunders, D. B., Kolek, E. A., Williams, E. A., \& Wells, R. S. (2016). Who is shaping the field? Doctoral education, knowledge creation and postsecondary education research in the United States. Higher Education Research \& Development. Published online Feb., 2016. Doi: 10.1080/07294360.2016.1139552

Shulman, L. S. (2005). Signature pedagogies in the professions. Daedalus, 134(3), 52-59. doi: $10.1162 / 0011526054622015$

Simpson, C., \& Sommer, D. (2016). The practice of professional doctorates: The case of a U.K. based distance DBA. Journal of Management Education, 40(5), 576-594. doi: 10.1177/1052562916652643

Stevens-Long, J., \& Schapiro, S. A., \& McClintock, C. (2012). Passionate Scholars: Transformative learning in doctoral education. Adult Education Quarterly, 62(2), 180-198.

The New England Resource Center for Higher Education. (2015). The Next Generation Engagement Project. Boston, MA: University of Massachusetts. Retrieved http://www.nerche.org/index.php?option=com_content\&view=article\&id=355\&Itemid=96

The Woodrow Wilson National Fellowship Foundation. (2005). The Responsive Ph.D.: Innovations in U.S. doctoral education. Princeton, NJ: Author.

Walker, G. E., Golde, C. M., Jones, L, Bueschel, A. C., \& Hutchings, P. (2008). The formation of scholars: Rethinking doctoral education for the twenty-first century. Jossey-Bass. ISBN: 978-0470197431

Willey, J., \& Seldomridge, L. A. (2016). Using the Tools of Technology to Increase Access to Doctoral Education: Best Practices in Distance Education. Virginia Henderson Global Nursing eRepository, Sigma Theta Tau International Honor Society of Nursing. http://www.nursinglibrary.org/vhl/handle/10755/602940

Organizations, websites, and other resources for review:

Carnegie Foundation for the Advancement of Teaching, Carnegie Initiate on the Doctorate (CID): http://archive.carnegiefoundation.org/previous-work/professional-graduate education

Council for Higher Education Accreditation: (a) http://www.chea.org/Directories/special.asp http://www.chea.org/Directories/regional.asp

Higher Learning Commission: https://www.hlcommission.org/

International Journal of Educational Reform: https://www.learntechlib.org/j/ISSN-1056-7879/

New England Resource Center for Higher http://www.nerche.org/index.php?option=com_content $\&$ view=article \&id=355\&Itemid=96

Society for Research into Higher Education: https://www.srhe.ac.uk/

U.S. Department of Education, The Database of Accredited Postsecondary Institutions and Programs, listing of accreditation institutions:

(a) http://ope.ed.gov/accreditation/agencies.aspx

(b) http://www2.ed.gov/admins/finaid/accred/accreditation_pg6.html 